\title{
Kontribusi Pelatihan Guru terhadap Implementasi Kurikulum 2013
}

\author{
Ririn Nurpendah ${ }^{1}$, Fahmi Rizal'2, Sukardi ${ }^{3}$ \\ ${ }^{123}$ Fakultas Teknik, Universitas Negeri Padang, Sumatera Barat
}

\begin{abstract}
Abstrak
Masalah dalam penelitian ini adalah masih banyaknya guru yang kurang memahami penilaian menggunakan tiga aspek yaitu: pengetahuan, keterampilan dan sikap. Hal tersebut terlihat dari masih banyaknya guru yang kesulitan dalam

Kata Kunci:

Pelatihan Guru, Kurikulum 2013 melaksanakan penilaian sikap siswa melalui rubrik penilaian sikap, perubahan pola pikir guru juga menjadi hal yang sulit untuk diubah, hal ini dikarenakan guru sudah lama mengajar dengan kurikulum KTSP, namun dituntut untuk mengubahnya pada kurikulum baru yaitu kurikulum 2013, sehingga dibutuhkan pelatihan maupun sosialisasi kurikulum 2013 secara berkelanjutan. Selanjutnya model pembelajaran learning direct instruction yang masih kurang maksimal dilaksanakan oleh guru, kurangnya pemanfaatan media pembelajaran sebagai alat pendukung pembelajaran, sehingga pembelajaran yang dilaksanakan SMKN 1 Sumbar kurang bervariasi. Tujuan penelitian yaitu untuk menjelaskan hubungan pelatihan guru dengan implementasi kurikulum 2013 di SMKN 1 Sumbar. Penelitian ini menggunakan jenis penelitian kuantitatif korelasional. Berdasarkan hasil penelitian diperoleh hasil bahwa terdapat hubungan yang positif dan signifikan pelatihan guru dengan implementasi kurikulum 2013 di SMK 1 Sumbar dengan persentase kontribusi sebesar 79,9\%.
\end{abstract}

\begin{abstract}
The problem in this study was there are still many teachers who do not understand the assessment using three aspects: knowledge, skills and attitudes. It can be seen from the fact that there are still many teachers who have difficulty in assessing student attitudes through the attitude assessment rubric, changing the teacher's mindset is also a difficult thing to change, because the teacher has been teaching with KTSP curriculum for a long time, but required to change it to the new curriculum, curriculum 2013, so that training and socialization of the 2013 curriculum needed on an ongoing basis. Furthermore, the direct instruction learning model still not maximally implemented by the teacher, the lack of learning media as a learning support tool, so that the learning carried out by SMKN 1 Sumbar is less varied. The research objective is to explain the relationship between teacher training and the implementation of the 2013 curriculum at SMKN 1 Sumbar. This research uses correlational quantitative research. Based on the results of the study, it was found that there was a positive and significant relationship between teacher training and the implementation of the 2013 curriculum at SMK 1 Sumbar with a contribution percentage was $79.9 \%$.
\end{abstract}

\footnotetext{
* Corresponding author.

E-mail Addresses: ririnnur44@gmail.com (Ririn Nurpendah)
} 


\section{PENDAHULUAN}

Secara filosofis, Kurikulum 2013 di Indonesia dikembangkan atas dasar pemikiran bahwa pendidikan berakar pada budaya bangsa untuk membangun kehidupan bangsa masa kini dan masa mendatang. Pandangan ini menjadikan Kurikulum 2013 dikembangkan berdasarkan budaya bangsa Indonesia yang beragam, diarahkan untuk membangun kehidupan masa kini, dan untuk membangun dasar bagi kehidupan bangsa yang lebih baik di masa depan. Peserta didik adalah pewaris Pendidikan ditujukan untuk mengembangkan kecerdasan intelektual dan kecemerlangan akademik melalui pendidikan disiplin ilmu. Filosofi ini menentukan bahwa isi kurikulum adalah disiplin ilmu dan pembelajaran adalah pembelajaran disiplin ilmu (essentialism). Pendidikan untuk membangun kehidupan masa kini dan masa depan yang lebih baik dari masa lalu dengan berbagai kemampuan intelektual, kemampuan berkomunikasi, sikap sosial, kepedulian, dan berpartisipasi untuk membangun kehidupan masyarakat dan bangsa yang lebih baik (experimentalism and social reconstructivism). Menurut pandangan filosofis ini, prestasi bangsa di berbagai bidang kehidupan di masa lampau adalah sesuatu yang harus termuat dalam kurikulum untuk dipelajari oleh peserta didik (Mulyoto, 2013; Hanif, 2014; dan Suarga, 2017). Kurikulum 2013 merupakan Kurikulum yang baru dirancang oleh pemerintah untuk menjadikan pendidikan di Indonesia jauh lebih baik dari pada sebelumnya. Kurikulum 2013 dirancang untuk menyempurnakan Kurikulum sebelumnya yaitu Kurikulum Tingkat Satuan Pendidikan atau lebih kenal sebagai KTSP. Sebagai penunjang tercapainya pendidikan yang diharapkan pemerintah. Pemerintah selalu mengembangkan Kurikulum di Indonesia ini dibuktikan dengan banyaknya perubahan Kurikulum dari waktu ke waktu.Kebudayaan terus melakukan pembaharuan dalam bidang pendidikan salah satunya adalah pembaharuan Kurikulum yakni lahirnya Kurikulum 2013. Lahirnya Kurikulum ini untuk menjawab tantangan dan pergeseran paradigma pembanguanan dari abad ke-20 menuju abad ke-21. Kurikulum 2013 bertujuan untuk mempersiapkan manusia Indonesia agar memiliki kemampuan hidup sebagi pribadi dan warga negara yang beriman, produktif, kreatif, inovatif dan evektif serta mampu berkontribusi pada kehidupan bermasyarakat, berbangsa, bernegara dan peradaban dunia.

Sekian banyak unsur dari sumber daya pendidikan, Menurut Thaib dan Siswanto (2015) Kurikulum merupakan jabaran materi-materi yang disajikan dalam pembelajaran, juga merupakan komponen yang sangat penting dalam suatu sistem pendidikan, kurikulum merupakan alat untuk mencapai tujuan pendidikan dan sekaligus sebagai pedoman dalam pelaksanaan pengajaran pada semua jenis dan tingkat pendidikan. Sedangkan Menurut Bahri (2011) kurikulum adalah kumpulan seperangkat nilai yang dirancang untuk ditransformasikan kepada subjek didik, baik nilai-nilai dalam bentuk kognitif, afektif maupu psikomotor. dengan memperoleh seperangkat nilai tersebut, pola pikir dan perilaku subjek didik akan terbentuk sesuai dengan arah dan tujuan yang sudah diformulasikan sebelumnya, yaitu kurikulum. Kurikulum adalah salah satu unsur yang bisa memberikan kontribusi yang signifikan untuk mewujudkan proses berkembangnya kualitas potensi peserta didik. Jadi tidak dapat di pungkiri bahwa Kurikulum yang dikembangkan dengan berbasis pada kompetensi sangat diperlukan sebagai instrumen untuk mengarahkan peserta didik menjadi: (1) manusia berkualitas yang mampu dan proaktif menjawab tantangan zaman yang selalu berubah; (2) manusia terdidik yang beriman dan bertakwa kepada Tuhan Yang Maha Esa, berakhlak mulia, sehat, berilmu, cakap, kreatif, mandiri; dan (3) warga negara yang demokratis dan bertanggung jawab. Pengembangan dan pelaksanaan Kurikulum berbasis kompetensi merupakan salah satu strategi pembangunan Pendidikan Nasional sebagai mana yang di amanatkan dalam Undang-undang Nomor 20 Tahun 2003 tentang sistem Pendidikan Nasional.

Terbentuknya Kurikulum 2013 pemerintah banyak memberikan pelatihan-pelatihan untuk kepala sekolah dan guru supaya Kurikulum 2013 ini bisa diterapkan yang diinginkan pemerintah. Implementasi Kurikulum 2013 dibentuk supaya pemerintah pusat dan pemerintahan daerah dapat melakukan usaha bersama untuk bertanggung jawab dalam mempersiapkan pelaksanaan Kurikulum sampai ke sekolah dengan baik. Tujuan pelatihan diadakan oleh pemerintah pusat dan daerah agar Kurikulum 2013 dapat tercapai sesuai yang diinginkan oleh pihak terkait yang diatur pada Undangundang dasar (Nomor 70 tahun 2013) yaitu "Untuk mempersiapkan manusia indonesia agar memiliki kemampuan hidup sebagai pribadi dan warga negara yang beriman, produktif, kreatif, inovatif, dan efektif serta mampu berkontribusi pada kehidupan bermasyarakat, berbangsa, bernegara dan peradaban dunia".

Materi pembelajaran yang dirampingakan dan materi yang ditambah akan berdampak pada banyaknya jam belajar yang harus diikuti oleh siswa, dan membuat Kurikulum ini menjadi kurang efektif. Perubahan-perubahan yang sering terjadi dalam Kurikulum bangsa ini membuat siswa dan guru sebagai pengajar kebingungan, Siswa harus menyesuaikan cara belajar sedangkan guru harus mampu menerapkan metode dan strategi mengajar yang sesuai dengan aturan yang baru. Hal tersebut dapat memicu ketidak efektifan dalam kegiatan belajar mengajar.Namun keluarnya Kurikulum ini bukan tanpa hambatan, kurangnya sosialisasi dari pemerintah serta kurangnya pengalaman guru dalam membuat 
Kurikulum mengakibatkan dampak negatif baik bagi siswa maupun guru. Seperti permasalahan sebelumnya dalam Kurikulum ini juga terdapat kebingungan, materi yang seharusnya ada di semester pertama (pada Kurikulum sebelumnya) dipelajari lagi pada semester kedua (pada Kurikulum baru) sehingga siswa harus mempelajari mata pelajaran yang sudah mereka ketahui sebelumnya.

Implementasi kurikulum itu sendiri dipengaruhi oleh beberapa faktor berupa model learning direct instruction, pelatihan guru, keterampilan guru abad 21, minat siswa dan beberapa faktor lainnya yang mempengaruhi implementasi kurikulum 2013. Berdasarkan observasi dan pengamatan langsung yang peneliti lakukan di lapangan yaitu pada SMKN 1 Sumbar ditemukan informasi bahwa masih banyaknya guru yang kurang memahami penilaian menggunakan tiga aspek yaitu: pengetahuan, keterampilan dan sikap. Hal tersebut terlihat dari masih banyaknya guru yang kesulitan dalam melaksanakan penilaian sikap siswa melalui rubrik penilaian sikap. Para guru lebih fokus kepada nilai pengetahuan/kognitif yang diperoleh siswa melalui Ulangan Harian (UH) ataupun Ujian Akhir Semester (UAS) yang diperoleh siswa. Penilaian sikap yang selama ini dilakukan oleh guru hanya berupa pengamatan secara menyeluruh kepada proses pembelajaran yang dilaksanakan oleh siswa. Dengan adanya penilaian sikap melalui rubrik ini memberikan kerumitan tersendiri bagi guru. Hal ini disebabkan para guru merasa penilaian menggunakan rubrik tersebut begitu menyita waktu dan mengurangi waktu penyampaian materi.

Selanjutnya perubahan pola pikir guru juga menjadi hal yang sulit untuk diubah, hal ini dikarenakan guru sudah lama mengajar dengan kurikulum KTSP, namun dituntut untuk mengubahnya pada kurikulum baru yaitu kurikulum 2013, sehingga dibutuhkan pelatihan maupun sosialisasi kurikulum 2013 secara berkelanjutan. Mayoritas guru masih mengalami gagap teknologi, hal ini membutuhkan penanganan yang lebih serius oleh pemerintah. Pengembangan kurikulum harus diikuti dengan sosialisasi dan pelatihan yang intens dengan melibatkan seluruh guru. Hal ini bertujuan untuk memaksimalkan penerapan kurikulum 2013. Masalah selanjutnya yang peneliti temukan di lapangan adalah model pembelajaran learning direct instruction yang masih kurang maksimal dilaksanakan oleh guru. Sedangkan pada kurikulum 2013 siswa dituntut untuk lebih aktif dan guru berperan sebagai fasilitator, namun para guru di SMKN 1 Sumbar belum mampu memposisikan dirinya sebagai fasilitator. Sehingga tujuan pembelajaran yang telah digariskan oleh kurikulum 2013 belum tercapai secara maksimal. Hal ini terlihat dari metode pembelajaran dan strategi pembelajaran yang digunakan oleh para guru. Mayoritas guru masih menggunakan sistem teacher center learning, yang berfokus kepada guru sebagai penyampai materi. Sehingga pembelajaran belum melibatkan peran aktif siswa seutuhnya.

Selain masalah yang dikemukakan di atas, terdapat beberapa masalah lainnya yang tidak kalah penting yaitu: kurangnya pemanfaatan media pembelajaran sebagai alat pendukung pembelajaran, sehingga pembelajaran yang dilaksanakan SMKN 1 Sumbar kurang bervariasi. Sedangkan pada kurikulum 2013 guru dituntut mampu melakukan variasi dalam pembelajaran melalui pemanfaatan media pembelajaran seperti: infocus, e-modul dan e-learning dan berbagai variasi lainnya. Ditambah lagi dengan kurangnya kesadaran guru SMKN 1 Sumbar dalam mengikuti pelatihan kurikulum 2013. Sehingga berdampak terhadap proses pembelajaran. Masalah selanjutnya yang ditemukan di lapangan adalah keterampilan guru yang ada di SMKN 1 Sumbar masih belum memadai dan kurang mampu mengikuti perkembangan pembelajaran pada abad 21. Dimana masih banyak guru yang kurang mampu menggunakan media pendukung pembelajaran, kurangnya komunikasi yang baik antar guru, kurang mampunya guru dalam berfikir kritis dan kurangnya kemampuan berfikir kreatif yang dimiliki oleh para guru di SMK 1 Sumbar. Dengan kurangnya keterampilan yang dimiliki guru, membuat materi pembelajaran belum tersampaikan secara optimal. Hal tersebut secara tidak langsung memberikan dampak kepada hasil belajar siswa itu sendiri.

Berdasarkan beberapa masalah yang telah dikemukakan di atas, maka peneliti ingin meneliti masalah tersebut ke dalam sebuah penelitian yang berjudul "Kontribusi Pelatihan Guru Terhadap Implementasi Kurikulum 2013 di SMKN 1 Sumbar".

\section{METODE PENELITIAN}

Jenis penelitian ini adalah kuantitatif dengan menggunakan jenis penelitian bersifat korelasional. Pelaksanaan penelitian ini dilakukan melalui pengumpulan data sebagai informasi yang kemudian diolah dalam bentuk data-data statistik untuk diketahui adanya hubungan antara variabel. Dalam pelaksaan penelitian, peneliti tidak memberikan perlakuan tambahan terhadap subjek penelitian. Penelitian ini dimaksudkan untuk memperoleh gambaran tentang hubungan antar variabel pada subjek penelitian, sebagaimana telah digambarkan oleh teori-teori pada masing-masing variabel. Hasil penelitian disusun dan ditulis melalui pendekatan deskriptif kuantitatif karena menggambarkan dan menganalisis hasil dari data statistik penelitian. Data yang diperoleh kemudian diolah melalui teknik korelasi dan regresi yang 
disajikan dalam bentuk angka-angka nilai korelasi dan regresi. Dalam penelitian ini penulis bertujuan untuk mengetahui hubungan pelatihan guru terhadap implementasi kurikulum 2013.

Teknik sampling yang digunakan adalah total sampling. Sampel dalam penelitian ini adalah seluruh guru di SMKN 1 Sumbar yang berjumlah 75 orang guru. Instrumen penelitian yang digunakan pada penelitian ini adalah instrument non tes berupa angket. Ujicoba instrument dilakukan kepada validator ahli dan kepada guru di luar sampel penelitian. Sumber data yang digunakan pada penelitian ini adalah data primer yang didapatkan langsung dari responden yaitu dengan membagikan angket kepada guru yang ada di SMKN1 Sumbar yang telah terpilih menjadi sampel. Dan juga data sekunder yang telah lebih dulu dikumpulkan dan dilaporkan oleh orang atau instansi diluar peneliti sendiri, seperti data jumlah guru di SMKN 1 Sumbar. Analisis data dilaksanakan dengan pengujian normalitas, linieritas dan pengujian hipotesis.

\section{ANALISIS DAN PEMBAHASAN}

Pada bagian deskripsi data ini diuraikan secara detail mengenai kontribusi pelatihan guru terhadap implementasi kurikulum 2013 di SMKN 1 Sumbar. Pada penelitian ini yang dijadikan objek penelitian adalah seluruh guru di SMKN 1 Sumbar. Setelah dilakukan penarikan sampel secara total sampling, maka diperoleh sampel sebanyak 75 orang guru. Seluruh data hasil penelitian yang masuk dan memenuhi syarat, diolah dan dianalisis untuk mengungkapkan informasi sesuai dengan tujuan penelitian. Secara singkat dapat dinyatakan bahwa deskripsi data penelitian variabel X dan Y dapat dilihat pada Tabel 1:

Tabel 1. Data Responden Variabel (X) dan (Y)

\begin{tabular}{lccc}
\hline & & $\mathbf{X}$ & $\mathbf{Y}$ \\
\hline \multirow{2}{*}{$\mathbf{N}$} & Valid & $\mathbf{7 5}$ & $\mathbf{7 5}$ \\
\cline { 2 - 4 } & Missing & $\mathbf{0}$ & $\mathbf{0}$ \\
\hline Mean & 149.4533 & 162.6000 \\
Std. Error of Mean & 1.77665 & 1.84313 \\
Median & 151.0000 & 164.0000 \\
Mode & 151.00 & 164.00 \\
Std. Deviation & 15.38628 & 15.96195 \\
Variance & 236.738 & 254.784 \\
Range & 74.00 & 80.00 \\
Minimum & 111.00 & 120.00 \\
Maximum & 185.00 & 200.00 \\
Sum & 11209.00 & 12195.00 \\
\hline
\end{tabular}

Sumber: Pengolahan Data Mandiri, 2020

Variabel pelatihan guru diuji menggunakan instrumen berbentuk angket yang terdiri dari 37 butir angket yang telah diuji validitas dan reliabilitasnya. Berdasarkan analisis statistik diperoleh jumlah data $(\mathrm{N})$ yang diisi sebanyak 75 orang responden, rata-rata (mean) pada tiap skor jawaban sebesar 149.4533, dengan hasil jawaban terkecil ( $\mathrm{min}$ ) yang dijawab oleh responden diperoleh 111, hasil jawaban terbanyak (max) yang dijawab oleh responden diperoleh 185, sedangkan standar deviasi dari masingmasing skor jawaban responden diperoleh sebesar 15,38628. Selanjutnya median untuk variabel pelatihan guru adalah 151, dengan modus sebesar 151. Distribusi frekuensinya dapat dilihat pada Tabel 2:

Tabel 2. Distribusi Frekuensi Variabel Pelatihan Guru

\begin{tabular}{cccccc}
\hline & & Frequency & Percent & Valid Percent & Cumulative Percent \\
\hline \multirow{6}{*}{ Valid } & 111.00 & 1 & 1.3 & 1.3 & 1.3 \\
& 116.00 & 1 & 1.3 & 1.3 & 2.7 \\
& 121.00 & 2 & 2.7 & 2.7 & 5.3 \\
& 127.00 & 4 & 5.3 & 5.3 & 10.7 \\
& 133.00 & 6 & 8.0 & 8.0 & 18.7 \\
& 139.00 & 9 & 12.0 & 12.0 & 30.7 \\
& 145.00 & 11 & 14.7 & 14.7 & 45.3 \\
& 151.00 & 12 & 16.0 & 16.0 & 61.3 \\
\hline
\end{tabular}




\begin{tabular}{ccccc}
\hline & Frequency & Percent & Valid Percent & Cumulative Percent \\
\hline 157.00 & 10 & 13.3 & 13.3 & 74.7 \\
163.00 & 8 & 10.7 & 10.7 & 85.3 \\
168.00 & 5 & 6.7 & 6.7 & 92.0 \\
173.00 & 3 & 4.0 & 4.0 & 96.0 \\
179.00 & 2 & 2.7 & 2.7 & 98.7 \\
185.00 & 1 & 1.3 & 1.3 & 100.0 \\
\hline Total & $\mathbf{7 5}$ & $\mathbf{1 0 0 . 0}$ & $\mathbf{1 0 0 . 0}$ & \\
\hline & & \multicolumn{3}{c}{ Sumber: Pengolahan Data Mandiri, 2020 }
\end{tabular}

Variabel implementasi kurikulum 2013 diuji menggunakan instrumen berbentuk angket yang terdiri dari 40 butir angket yang telah diuji validitas dan reliabilitasnya. Berdasarkan analisis statistik diperoleh jumlah data $(\mathrm{N})$ yang diisi sebanyak 75 orang responden, rata-rata (mean) pada tiap skor jawaban sebesar 162,6000, dengan hasil jawaban terkecil (min) yang dijawab oleh responden diperoleh 120, hasil jawaban terbanyak (max) yang dijawab oleh responden diperoleh 200, sedangkan standar deviasi dari masing-masing skor jawaban responden diperoleh sebesar 15,96195. selanjutnya median untuk variabel implementasi kurikulum 2013 adalah 164, dengan modus sebesar 164. Distribusi frekuensinya dapat dilihat pada Tabel 3:

Tabel 3. Distribusi Frekuensi Variabel Implementasi Kurikulum 2013

\begin{tabular}{cccccc}
\hline & Frequency & Percent & Valid Percent & Cumulative Percent \\
\hline \multirow{6}{*}{ Valid } & 1 & 1.3 & 1.3 & 1.3 \\
& 120.00 & 1 & 1.3 & 1.3 & 2.7 \\
& 127.00 & 2.7 & 2.7 & 5.3 \\
& 134.00 & 2 & 5.3 & 5.3 & 10.7 \\
& 140.00 & 4 & 8.0 & 8.0 & 18.7 \\
& 146.00 & 6 & 12.0 & 12.0 & 30.7 \\
& 152.00 & 9 & 14.7 & 14.7 & 45.3 \\
& 158.00 & 11 & 16.0 & 16.0 & 61.3 \\
& 164.00 & 12 & 13.3 & 13.3 & 74.7 \\
& 170.00 & 10 & 10.7 & 10.7 & 85.3 \\
& 176.00 & 8 & 6.7 & 6.7 & 92.0 \\
& 182.00 & 5 & 4.0 & 4.0 & 96.0 \\
& 188.00 & 3 & 2.7 & 2.7 & 98.7 \\
& 194.00 & 2 & 1.3 & 1.3 & \\
& 200.00 & 1 & $\mathbf{1 0 0 . 0}$ & $\mathbf{1 0 0 . 0}$ & \\
\hline Total & $\mathbf{7 5}$ & & Sumber: Pengolahan Data Mandiri, 2020
\end{tabular}

Selanjutnya untuk melihat kontribusi pelatihan guru (X) terhadap implementasi kurikulum 2013 (Variabel Y) maka dilakukan persyaratan analisis hipotesis (uji normalitas dan linieritas), uji hipotesis dan pembahasan terhadap hasil penelitian. Uji normalitas digunakan untuk mengetahui apakah populasi data berdistribusi normal atau tidak. Uji normalitas dilakukan dengan menggunakan rumus kolmogorovsmirnov dengan bantuan aplikasi IBM SPSS 21. Hasil uji normalitas dapat dilihat pada Tabel 4 berikut:

Tabel 4. Uji Normalitas

\begin{tabular}{clcc}
\hline \multicolumn{4}{c}{ One-Sample Kolmogorov-Smirnov Test } \\
\hline & $\mathbf{X}$ & $\mathbf{Y}$ \\
\hline & $\mathbf{N}$ & $\mathbf{7 5}$ & $\mathbf{7 5}$ \\
\hline \multirow{2}{*}{ Normal Parameters ${ }^{\mathrm{a}, \mathrm{b}} \mathrm{b}$} & Mean & 149,4533 & 162,6000 \\
& Std, Deviation & 15,38628 & 15,96195 \\
\multirow{2}{*}{ Most Extreme Differences } & Absolute & 0,087 & 0,082 \\
& Positive & 0,073 & 0,078 \\
& Negative & $-0,087$ & $-0,082$ \\
\hline \multicolumn{2}{c}{ Kolmogorov-Smirnov Z } & $\mathbf{0 , 7 5 1}$ & $\mathbf{0 , 7 0 7}$ \\
\hline
\end{tabular}




\begin{tabular}{ccc}
\hline \multicolumn{4}{c}{ One-Sample Kolmogorov-Smirnov Test } & \\
\hline & $\mathrm{X}$ & $\mathrm{Y}$ \\
\hline $\mathrm{N}$ & 75 & 75 \\
\hline Asymp, Sig, (2-tailed) & 0,626 & 0,700 \\
\hline
\end{tabular}

Tabel 4 menunjukkan probabilitas (sign) ketiga variabel $>\alpha=0,05$. Probabilitas (sign) variabel pelatihan guru (X) sebesar 0,626 dan variabel implementasi kurikulum 2013 (Y) sebesar 0,700. Dengan demikian dapat disimpulkan bahwa Ha diterima dan berdasarkan hasil analisis tersebut dapat dinyatakan bahwa data kedua variabel berdistribusi normal. Hal ini menunjukkan bahwa salah satu syarat untuk pengujian hipotesis sudah dipenuhi.

Uji linieritas dilakukan untuk melihat apakah masing-masing data variabel pelatihan guru (X) cenderung membentuk distribusi garis linear terhadap variabel implementasi kurikulum 2013 (Y). Hasil perhitungan uji linieritas variabel pelatihan guru (X) terhadap implementasi kurikulum 2013 (Y) disajikan pada Tabel 5.

Tabel 5. Hasil Uji Linieritas Variabel X dan Y

\begin{tabular}{|c|c|c|c|c|}
\hline \multicolumn{5}{|c|}{ ANOVA Table } \\
\hline & & & $\mathrm{F}$ & Sig. \\
\hline \multirow{5}{*}{$\mathrm{Y}^{*} \mathrm{X}$} & \multirow{3}{*}{ Between Groups } & (Combined) & 151,007 & 0,000 \\
\hline & & Linearity & 1482,132 & 0,000 \\
\hline & & $\begin{array}{l}\text { Deviation from } \\
\text { Linearity }\end{array}$ & 3,104 & 0,003 \\
\hline & \multicolumn{2}{|c|}{ Within Groups } & & \\
\hline & \multicolumn{2}{|c|}{ Total } & & \\
\hline
\end{tabular}

Berdasarkan Tabel 5 di atas, diperoleh probabilitas linearity (sign) sebesar 0,000 lebih kecil dari 0,05 maka dapat disimpulkan bahwa sebaran data variabel bebas membentuk garis linear terhadap variabel terikat. Karena pengujian linieritas telah terpenuhi, maka dapat dilanjutkan dengan uji hipotesis. Berdasarkan hasil analisis korelasi sederhana antara pelatihan guru dengan implementasi kurikulum 2013 di SMK 1 Sumbar dapat dilihat pada Tabel 6 berikut ini.

Tabel 6. Hasil Analisis Korelasi Sederhana Variabel Pelatihan Guru dengan Implementasi Kurikulum 2013

\begin{tabular}{lcccc}
\hline & \multicolumn{3}{c}{ Model Summary } \\
\hline Model & $\mathbf{R}$ & R Square & Adjusted R Square & Std, Error of the Estimate \\
\hline 1 & $0,799^{\mathrm{a}}$ & 0,799 & 0,799 & 0,56993 \\
\hline a, Predictors: (Constant), $X 2$ & & & \\
\hline
\end{tabular}

Berdasarkan analisis korelasi sederhana pada Tabel 6 tersebut, dapat diketahui harga koefisien korelasi $\mathrm{r}_{\text {hitung }}$ untuk $\mathrm{N}=75$ dan taraf kesalahan sebesar $5 \%$ adalah $\mathrm{r}_{\text {tabel }}=0,227$. Dengan ketentuan apabila ( $\left.\mathrm{r}_{\text {hitung }}<\mathrm{rt}_{\text {abel }}\right)$ maka tidak terdapat kontribusi antara pelatihan guru dengan implementasi kurikulum 2013 di SMKN 1 Sumbar $\left(\mathrm{H}_{0}\right)$. Selanjutnya jika $\left(\mathrm{r}_{\text {hitung }}>\mathrm{r}_{\text {tabel }}\right)$ maka terdapat kontribusi antara pelatihan guru dengan implementasi kurikulum 2013 di SMKN 1 Sumbar $\left(\mathrm{H}_{\mathrm{a}}\right)$. Berdasarkan hasil analisis yang dilakukan diperoleh nilai $r_{\text {hitung }}>r_{\text {tabel }}(0,799>0,227)$.

Hal tersebut menunjukkan bahwa pelatihan guru memiliki hubungan yang positif dengan implementasi kurikulum 2013 yaitu sebesar 0,799. Sehingga dapat disimpulkan bahwa pelatihan guru dengan implementasi kurikulum 2013 memiliki korelasi yang signifikan pada taraf kesalahan 5\%. Nilai korelasi tersebut menunjukkan korelasi yang sedang antara pelatihan guru dengan implementasi kurikulum 2013 di SMKN 1 Sumbar, seperti yang diungkapkan oleh Sugiyono (2009:257) bahwa secara kuantitatif interval nilai 0,400-0,799 maka tingkat korelasi/hubungan antar variabel adalah sedang. Berdasarkan uraian yang telah dijabarkan tersebut dapat ditarik kesimpulan bahwa pelatihan guru memiliki hubungan yang positif dengan implementasi kurikulum 2013 di SMKN 1 Sumbar yakni sebesar 0,799 . Selanjutnya pada tabel 6 diperoleh harga $r_{\text {hitung }}=0,799$ dan $r_{\text {tabel }}=0,227$. Sehingga dapat dikatakan $r_{\text {hitung }}(0,799)>r_{\text {tabel }}(0,227)$ atau signifikan<alpha $(0,000<0,005)$ maka diperoleh $r_{\text {square }}$ sebesar 0,799 . Ini menunjukkan bahwa kontribusi yang terjadi antara pelatihan guru dengan implementasi kurikulum 2013 
adalah sebesar 0,799 atau sebesar 79,9\%, berarti semakin baik pelatihan guru, maka semakin baik juga implementasi kurikulum 2013. Hal tersebut menunjukkan bahwa pelatihan guru berkontribusi positif terhadap implementasi kurikulum 2013 sebesar 79,9\%.

Tabel 7. Hasil Analisis Korelasi Sederhana Variabel $\mathrm{X}_{2}$ dengan Y Menggunakan Tabel Coefficient

\begin{tabular}{|c|c|c|c|c|c|c|}
\hline \multicolumn{7}{|c|}{ Coefficients $^{a}$} \\
\hline & \multirow[t]{2}{*}{ Model } & \multicolumn{2}{|c|}{ Unstandardized Coefficients } & \multirow{2}{*}{$\begin{array}{c}\begin{array}{c}\text { Standardized } \\
\text { Coefficients }\end{array} \\
\text { Beta }\end{array}$} & \multirow[t]{2}{*}{$\mathbf{t}$} & \multirow[t]{2}{*}{ Sig, } \\
\hline & & $\mathbf{B}$ & Std, Error & & & \\
\hline \multirow{2}{*}{1} & (Constant) & 7,653 & 0,647 & & 11,830 & 0,000 \\
\hline & $\mathrm{X} 2$ & 1,037 & 0,004 & 0,799 & 240,774 & 0,000 \\
\hline
\end{tabular}

Berdasarkan Tabel 7 tersebut dapat dilakukan uji T untuk menguji tingkat beda antara satu koefisien variabel independen tertentu dengan koefisien independen yang lainnya, apabila terdapat lebih dari satu variabel independen yang dihasilkan dari persamaan regresi dalam menentukan perubahan nilai variabel dependen yang dinilai dengan tingkat alpha 5\% yang merupakan kesalahan menolak data. Melalui penelitian ini diperoleh nilai signifikansi sebesar 0,000, konstanta yang terbentuk sebesar 7,653, sedangkan standar koefisien regresi yang terbentuk 1,037. Adapun bentuk persamaan regresi sederhana yang dihasilkan yaitu:

$$
Y=7,653+1,037 X_{2}
$$

Bentuk persamaan regresi di atas menjelaskan bahwa setiap peningkatan pelatihan guru sebesar 1 skala akan berkontribusi terhadap peningkatan implementasi kurikulum 2013 sebesar 1,037 skala. Sementara nilai untuk kinerja guru sudah ada sebesar 7,653 skala tanpa pelatihan guru. Berdasarkan tabel 7 tersebut diperoleh nilai $t$ untuk variabel pelatihan guru dengan nilai $t_{\text {hitung }}=11,830$ dengan nilai signifikansi yang diperoleh sebesar 0,000 . Untuk dapat mengetahui seberapa besar tingkat hubungan yang ada pada kedua variabel di atas, dapat dilakukan penilaian sebagai berikut. Jika nilai $t_{\text {hitung }}>t_{\text {tabel, }}$, maka terdapat hubungan yang signifikan, apabila $t_{\text {hitung }}<t_{\text {tabel }}$ maka tidak terdapat hubungan yang signifikan. Nilai tabel pada alpha $5 \%$ adalah $\mathrm{dk}=\mathrm{N}-2$ atau $\mathrm{dk}=75-2=73$, nilai tabel yaitu 1,992. Apabila dibandingkan $t_{\text {hitung }} 11,830$ dengan $t_{\text {tabel }} 1,992$, maka dapat diketahui bahwa nilai $t_{\text {hitung }}>t_{\text {tabel. }}$. Maka dari itu dapat disimpulkan bahwa terdapat hubungan antara pelatihan guru dengan implementasi kurikulum 2013 di SMKN 1 Sumbar.

Pada bagian pembahasan ini akan dijelaskan hasil penelitian mengenai kontribusi pelatihan guru terhadap implementasi kurikulum 2013 di SMKn 1 Sumbar. Pada bagian ini akan dibahas uraian masingmasing variabel. Berdasarkan pengujian hipotesis diperoleh nilai $t$ untuk variabel pelatihan guru dengan nilai $t_{\text {hitung }}=11,830$ dengan nilai signifikansi yang diperoleh sebesar 0,000 . Jika nilai $t_{\text {hitung }}>t_{\text {tabel, }}$ maka terdapat hubungan yang signifikan, apabila $\mathrm{t}_{\text {hitung }}<\mathrm{t}_{\text {tabel }}$ maka tidak terdapat hubungan yang signifikan. Nilai tabel pada alpha $5 \%$ adalah $\mathrm{dk}=\mathrm{N}-2$ atau $\mathrm{dk}=75-2=73$, nilai tabel yaitu 1,992. Apabila dibandingkan $t_{\text {hitung }} 11,830$ dengan $t_{\text {tabel }}$ 1,992, maka dapat diketahui bahwa nilai $t_{\text {hitung }}>t_{\text {tabel. }}$. Maka dari itu dapat disimpulkan bahwa terdapat hubungan antara pelatihan guru dengan implementasi kurikulum 2013 di SMKN 1 Sumbar.

Penelitian ini sejalan dengan penelitian yang dilakukan oleh [3] yang meneliti judul tentang: "Kesiapan Guru dalam Menghadapi Implementasi Kurikulum 2013 di MTs Al Fitroh Bonang Demak". Hasil penelitian ini disimpulkan bahwa kesiapan guru dalam menghadapi implementasi Kurikulum 2013 di MTs Al Fitroh Bonang Demak masih relatif rendah, hal ini diperkuat dengan sebagian besar guru yang mengajar masih menggunakan system Kurikulum KTSP 2006, dalam artian guru yang belum mengenal dan mengerti akan kurikulum mereka ini aktif untuk mengikuti kegiatan yang diadakan oleh sekolah ataupun Diknas. Selanjutnya penelitian ini juga relevan dengan penelitiannya [4] meneliti judul tentang: "Implementasi Kurikulum 2013 ditinjau dari Kesiapan Guru Mengajar Simulasi Digital di SMK Negeri kota Payakumbuh". Hasil dari penelitian ini disimpulkan bahwa penguasaan kompetensi profesional mencakup penguasaan substansi keilmuan bidang studi dan guru harus selalu meng-update, dan menguasai materi pelajaran yang disajikan. Persiapan diri tentang materi diusahakan dengan jalan mencari informasi melalui berbagai sumber seperti membaca buku terbaru, mengakses internet, selalu mengikuti perkembangan dan kemajuan terakhir tentang materi yang disajikan. 
Selanjutnya penelitian ini juga sejalan dengan penelitian yang dilakukan oleh [5] yang meneliti judul tentang: "Pendidikan dan pelatihan guru dalam meningkatkan kualitas pendidikan di SMPN 27 Sendawar Kabupaten Kutai Barat". Hasil dari penelitian ini disimpulkan bahwa Pendidikan dan pelatihan guru yang dilakukan Sekolah Menengah Pertama Negeri 27 Sendawar Kabupaten Kutai Barat, mampu meningkatkan keterampilan dan keahlian para guru di lembaga tersebut. Hal tersebut dapat dikatahui dari jumlah guru yang memiliki legalitas pelatihan sesuai mata pelajaran yang dibinanya. Meskipun upaya yang dilakukan belum sepenuhnya dapat mengakomodasi semua guru untuk mengikuti pelatihan, tetapi dari tindakan yang dilakukan dapat meningkatkan kompetensi sebagian besar guru.

Berdasarkan beberapa penelitian relevan tersebut, maka dapat disimpulkan bahwa penelitian relevan dan penelitian ini sama-sama berhasil membuktikan adanya kontribusi pelatihan guru terhadap implementasi kurikulum 2013.

\section{KESIMPULAN}

Dari hasil analisis penelitian tentang kontribusi pelatihan guru (X) terhadap implementasi kurikulum 2013 (Variabel Y) di SMKN 1 Sumbar, maka dapat ditarik kesimpulan yaitu: terdapat kontribusi pelatihan guru terhadap implementasi kurikulum 2013 di SMK 1 Sumbar sebesar 79,9\%. Dapat disimpulkan bahwa pelatihan guru terhadap implementasi kurikulum 2013 memiliki korelasi yang signifikan pada taraf kesalahan 5\%. Ini menunjukkan bahwa terdapat korelasi yang sangat kuat antara pelatihan guru terhadap implementasi kurikulum 2013. Dengan $\widehat{Y}$ prediksi apabila terdapat kenaikan 1 skala akan berkontribusi terhadap peningkatan implementasi kurikulum 2013 sebesar 1,037 skala. Sementara nilai untuk kinerja guru sudah ada sebesar 7,653 skala tanpa pelatihan guru.

Terimakasih yang tiada taranya saya ucapkan kepada kedua orangtua tersayang yang telah memberikan dukungan seutuhnya kepada saya, sehingga saya dapat menyelesaikan jurnal ini. Terimakasih yang tiada hentinya juga saya ucapkan kepada kedua pembimbing yang telah memotivasi dan memberikan bimbingan seutuhnya kepada saya dalam penyelesaian jurnal ini. Selanjutnya terimakasih saya sampaikan kepada rekan-rekan pejuang tesis yang bersama-sama memberikan dorongan dan semangat dalam setiap tahapan yang saya jalani. Terakhir, kepada seluruh pihak yang terlibat dalam penyelesaian tesis ini, saya ucapkan terimakasih.

\section{DAFTAR PUSTAKA}

Bahri, Syamsul. 2011. Pengembangan Kurikulum Dasar Dan Tujuannya. Jurnal Ilmiah Islam Futura Vol. XI No. 1, Hal. 16-34. Tersedia $\quad$ Pada: https://jurnal.arraniry.ac.id/index.php/islamfutura/article/view/61.

Binti, M. 2011. Implementasi Kompetensi Pedagogik Guru dalam Proses Pembelajaran Berbasis KTSP pada Mata Pelajaran IPS Ekonomi Kelas VIII di MTsN Malang III. Skripsi. Malang: Universitas Islam Negeri Maulana Malik Ibrahim.

Hanif, Muh. (2014). “Tinjauan Filosofis Kurikulum 2013” dalam Insania, Vol.19, No.1 [Januari-Juni], hlm.87-114.

Kemendikbud. 2014. Pengembangan Kurikulum 2013. Jakarta: Kementrian Pendidikan dan Kebudayaan.

Kunandar. 2014. Implementasi Kurikulum 2013. Jakarta: Rineka Cipta.

Mery. 2015. Implementasi Kurukulum 2013 ditinjau dari Kesiapan Guru Mengajar Simulasi Digital di SMKNegeri Kota Payakumbuh. Tesis: Universitas Negeri Padang.

Mulyoto. (2013). Strategi Pembelajaran di Era Kurikulm 2013. Jakarta: Prestasi Pustaka Raya.

Qomariyah. 2014. Pendidikan dan Pelatihan Guru dalam Meningkatkan Kualitas Pendidikan di SMP Negeri 27 Sendawar Kabupaten Kutai Barat. eJournal Administrative Reform. Vol 2 (3): 1811-1823.

Suarga. (2017). "Kerangka Dasar dan Landasan Pengembangan Kurikulum 2013" dalam Jurnal Pendidikan Alaudin, Vol.VI, No.1 [Januari-Juni], hlm.15-23. 
Thaib, Razali M., Irman Siswanto. 2015. Inovasi Kurikulum dalam Pengembangan Pendidikan (Suatu Analisis Implementatif). Jurnal Edukasi Vol 1, Nomor 2, Hal. 216-228. Tersedia Pada: https://jurnal.ar-raniry.ac.id/index.php/cobaBK/article/view/3231. 